\title{
Effective Management of Energy Consumption during the COVID-19 Pandemic: The Role of ICT Solutions
}

\author{
Wadim Strielkowski ${ }^{1, * \mathbb{D}}$, Irina Firsova ${ }^{2}$, Inna Lukashenko ${ }^{3}$, Jurgita Raudeliūnienè ${ }^{4, * \mathbb{D}}$ \\ and Manuela Tvaronavičienè 4 (D)
}

1 Department of Trade and Finance, Faculty of Economics and Management, Czech University of Life Sciences Prague, Kamýcká 129, Prague 6, 16500 Prague, Czech Republic

2 Department of Logistics and Marketing, Faculty of Economics and Business, Financial University under the Government of the Russian Federation, Leningradskiy Prospekt 55, 125993 Moscow, Russia; ifirsova@fa.ru

3 Department of World Finance, Faculty of International Economic Relations, Financial University under the Government of the Russian Federation, Leningradskiy Prospekt 49, 125993 Moscow, Russia; anelal@mail.ru

4 Department of Business Technologies and Entrepreneurship, Vilnius Gediminas Technical University, Sauletekio 11, 10223 Vilnius, Lithuania; manuela.tvaronaviciene@vgtu.lt

* Correspondence: strielkowski@pef.czu.cz (W.S.); jurgita.raudeliuniene@vgtu.lt (J.R.)

Citation: Strielkowski, W.; Firsova, I.; Lukashenko, I.; Raudeliūnienè, J.; Tvaronavičienè, M. Effective

Management of Energy Consumption during the COVID-19 Pandemic: The Role of ICT Solutions. Energies 2021 14, 893. https://doi.org/10.3390/ en14040893

Academic Editors: Nuno Carlos Leitão and Javier Contreras Received: 15 December 2020

Accepted: 3 February 2021

Published: 9 February 2021

Publisher's Note: MDPI stays neutra with regard to jurisdictional claims in published maps and institutional affiliations.

Copyright: (c) 2021 by the authors. Licensee MDPI, Basel, Switzerland. This article is an open access article distributed under the terms and conditions of the Creative Commons Attribution (CC BY) license (https:// creativecommons.org/licenses/by/ $4.0 /)$.

\begin{abstract}
This research tackles effective and functional management practices in energy consumption using advanced technological solutions to mitigate unexpected events. This study specifically focuses on the recent COVID-19 pandemic that led to a reduction in energy consumption and therefore meddled with the project management's status quo for the energy sources. Moreover, this research analyzes the role of information and communication technology (ICT) solutions in energy management before and after the recent coronavirus pandemic turmoil. This study also examined the role and place of sustainable energy resources in the effective management of energy consumption during the COVID-19 pandemic. The main purpose of this research is to demonstrate how the recent coronavirus pandemic affected energy consumption and energy prices in many countries and how it paved the way for the new ICT in managing energy consumption. This study elaborated a model to show how these changes evolved in selected European Union (EU) Member States. It turns out that adjusted electricity consumption, as well as the average daily spot electricity prices for the baseload power in the EU countries, declined, and this trend is likely to continue in the next years to come. Due to the COVID-19 pandemic, substantial changes in the economy led to reduced office space usage, cutting commuting and business trips, and bringing commercial travel almost to a halt, further shifting the energy balance towards renewable energy sources (RES). Besides, it becomes apparent that ICT solutions used in maintaining and superintending the energy balance are gaining popularity and wide recognition worldwide and will help pave the way towards modern and smart high-renewables grids.
\end{abstract}

Keywords: ICT solutions; project management; sustainable development; energy consumption; COVID-19; renewable energy

\section{Introduction}

As the pressure to meet the rising demand of energy can and will be alleviated by technological advances and the discovery of new sources, it seems that renewable energy sources (RES) will be the only viable alternative to fossil fuels in the near future [1,2]. While the European Union (EU) has long committed itself to its own (EU's 2030) targets for mitigating the effects of global warming and climate change by reducing at least $40 \%$ of its emissions and increasing the share of RES to $30 \%$ within the next 10 years [3-5], China is on track to transform the global energy landscape in a similar way following the United States and other major economies in recent years [6,7]. In China's case, this transition is possible because of its traditional carbon fuel reserves and because it has had 
to focus heavily on RES such as wind, solar, and geothermal energy [8,9]. Efforts have been made to dominate renewable energy technologies while increasing their energy efficiency and security. The United States has fallen behind China in developing its own energy technology, particularly in the areas of wind, solar, and geothermal energy [10,11]. Besides, it is important to mention the Chinese dominance in photovoltaics production, which is currently being exported to the rest of the world, with China becoming the major producer of this technology $[12,13]$.

As fossil fuel sources dwindle, some of the world's most influential states, including the United States, China, and Russia, are going to compete for energy resources (including establishing themselves as the major producers of renewable energy) while protecting and acquiring the world's remaining fossil fuel sources [14,15]. It seems likely that these countries' pace concerning clean energy moves could be determined by combining factors such as climate change, energy security, and economic growth. When energy security is necessary for energy supply, many countries use energy to ensure national security and enhance their global standing [16-18]. Therefore, energy plays an essential role in developing national economies and the global economy's growth. This could be particularly true for China, the world's second-largest energy consumer after the United States [19]. With its growing global power as a major energy consumer, China is on a course that could potentially transform the global energy landscape. It has already surpassed Germany, the EU Member State, in the production of photovoltaic power [20], while the rising United States demand for energy and renewable technology from China coincides with the growing strategic power of the twenty-first century [21]. This is partly due to the growth of China's economy and its rising energy needs, which coincided with a growing "strategic power" in the twentieth century. As the global players compete for a position as world powers, competition between states will intensify. Both China and the United States, the world's largest economies, are currently committed to the inclusion of renewable energy. It seems likely that China will include renewables in its energy mix, as indigenous coal is an important source of energy for the country's future energy needs. Moreover, coal is a non-renewable resource that is expected to run out by mid-century, which puts a certain pressure on the heavy users of coal such as China [22]. On the contrary, the United States possesses significant RES with the potential to be a world leader in energy efficiency and the ability to meet most of the country's energy needs over the next 50 years [23]. This is likely to become more relevant under the new United States administration that will take over the lead in 2021. The world's major powers influence the periphery to include renewable energy in their efforts to achieve energy security. As conventional energy prices continue to rise, it will affect countries' interest in alternative energy sources such as RES. Competition for energy sources also seems to be leading to new efforts in energy development. Competition for the remaining known reserves of natural gas, oil, coal, and other fossil fuels has intensified sharply. Some states seem to be acting to maintain or strengthen their overall power position, such as the United States, Russia, China, Iran, India, or Brazil. As a result, natural gas will play a larger role in the global energy mix than coal, oil, and other fossil fuels. The interaction of environmental and energy concerns will continue to shape the energy market. However, one should not forget that carbon-based fuels provide 80 percent of the world's energy and are expected to be produced from the carbon in two decades [24]. China is also home to the world's largest installed power generation capacity, with more than 1.5 billion megawatts [25].

The massive growth in demand forecasts, estimated by various sources, puts the potentially largest and most significant energy market in the world on track for a massive increase in energy demand over the next few decades. Primary energy demand will rise to 2.1 billion tons by 2020, which will increase global electricity production to about one-third of total global energy consumption by 2030 [26,27]. This estimate has been confirmed to represent about one-fifth of total global spending and is at the forefront of potentially the most ambitious energy growth forecasts in recent years [28]. All of the above makes 
effective energy management practices very relevant in energy consumption in the years to come.

However, effective management will depend not only on an effective demand-side response but also on the efficiency of information and communication technology (ICT) solutions that undoubtedly include the Internet of Energy (IoE) and autonomic power systems supported by fifth-generation (5G) wireless networks enabling quick two-way response and feedback. All of this will help to ensure that no "black swans" like the recent pandemic of COVID-19 will strike again in the nearest future to disrupt all the plans.

This research focuses on effective management practices in energy consumption during the COVID-19 pandemic and the role of ICT in these practices. This study is organized as follows. Section 2 describes the issues of energy resources and energy consumption. Section 3 elaborates on effective management practices for sustainable energy resources. Section 4 defines the project management processes and tools of energy consumption. Section 5 presents an empirical model of the impact of COVID-19 on energy consumption in selected EU countries. Section 6 characterizes the place of ICT solutions in the effective management of energy resources. Finally, Section 7 concludes the study by summarizing its primary outcomes and commenting on them, as well as presenting policy implications and pathways for further research.

\section{Energy Sources and Energy Consumption}

Every energy source, including renewable energy sources, has its own pitfalls, and customers have been paying a very high price for the use of fossil fuels for decades [29]. Energy sources that are currently in use can be divided into three main categories: primary, secondary, and tertiary. Primary energy sources include natural gas, coal, oil, nuclear, hydropower, wind, solar, geothermal, biomass, and hydropower. Electricity is a secondary energy source that is generated from a primary energy source. Secondary energy sources that generate or produce a primary energy source include wind, hydro, and solar (which are the best-known renewables), as well as other renewable sources [30,31]. RES become so ubiquitous that electricity from renewable sources is included in the calculations of primary energy consumption and converted into tons of oil equivalent using the same nuclear and hydropower method. Nevertheless, biofuel consumption will continue to be included in the data as oil consumption. In spite of that, fossil fuels, including coal, oil, and natural gas, are currently the world's primary energy sources. The input and conversion technology used to convert these fuels are counted as the source of fuel production and the output as consumption from the converted fuel. It is essential to state that fossil fuels, which have been produced from organic materials over millions of years, have driven economic development all around the world over the last century. Fossil fuels are a finite resource and can also do irreparable damage to the environment. Fossil fuel burning accounts for more than half of all greenhouse gas emissions worldwide and is crucial for climate change. Even by 2050, the effects of climate change are projected to cause up to 1.5 million deaths a year from global warming [32]. By 2050, renewables will account for an increasing share of electricity generation.

In most cases, fossil energy resources are currently more expensive to transport, store, and transport than RES [33,34]. They are stored and transported in the form of coal, oil, gas, and other fossil fuels, as well as coal and natural gas that require a lot of logistics and storage. Despite predictions of fossil fuel dominance, the use of RES is expected to increase. However, many hurdles to greater use of renewable energy must be overcome in order to produce and distribute it more economically. Renewable energy can be produced sustainably, but only if it is obtained from sources that can be renewed indefinitely, such as wind, solar, geothermal, hydropower and biomass. Energy is generated from a wide range of sources, from wind and solar to hydropower, biomass, and hydrofluorocarbons to other sources. It is estimated that the renewable energy market will grow at an annual rate of $1.9 \%$, based on estimates from the International Energy Agency (IEA) and the National Renewable Energy Laboratory [35]. This type of energy is less valuable because 
the cost per kWh depends on the available energy source, not on whether the source is turned on to produce electricity when needed. Thence, a reasonable and balanced demandside response is always required in order to manage its use under the appropriate terms. Although the technology for creating peepholes was developed specifically for very high electricity demand periods, it can overestimate its value. This could be competitive with many existing technologies if the full social costs of energy generation are considered.

To sum it up, there are many unsolved issues in managing the renewable energy sources, however potentially appealing, useful, and promising concerning mitigation of climate change and global warming they might seem. Thence, solid management solutions supported by digital technologies might be required in order to facilitate their widespread implementation and deployment on the path towards decarbonization and a sustainable future.

\section{Effective Management Practices for Sustainable Energy Resources}

Effective energy management includes many aspects featuring energy conservation, demand-side response, and energy efficiency [36]. For example, deep energy retrofits are part of the whole-building analysis and construction process, which can be achieved by modernizing lighting as well as heating, ventilation, and an air-conditioning (HVAC) system [37,38]. All of these are, for example, embedded into the concept of the so-called "smart house". All these meters and sensors used for managing smart houses address many of these systems by adopting a "holistic" approach and combining energy efficiency improvements such as controlled ventilation, air conditioning, and energy-efficient lighting. Electronic interactive graphics and dashboards provide the opportunity to inform residents about their building's energy and water consumption and might have an impact on their energy consumption and their demand-side response [39]. Most countries have these meters and sensors controlled and managed using some form of specially designated authorities. For example, in the United States, advanced energy upgrade guidelines are governed by the Energy Information Administration (EIA) and the Department of Energy and the National Renewable Energy Laboratory (NREL) [40]. Advanced guidelines for energy-related refurbishment and identifying possibilities for designing conversions are also available at, among other places, the Institute for Energy Efficiency and Renewable Energies website. They have led health organizations such as hospitals, nursing homes, and nursing schools, and leading energy-efficient companies that introduced advanced energy and sustainability practices at their facilities. In addition to improving energy efficiency and reducing energy use, the Department of Energy has reduced the energy consumption of more than 1.5 million homes and businesses in the United States [41]. Using advanced technologies that have emerged from laboratories, innovators in energy management came up with the share evidence-based technologies and market solutions that proved to help save energy. This constitutes a clear path to identifying straightforward ways to save money and energy. Various public and private sector organizations have started to optimize by implementing effective policies and practices for energy efficiency and renewable energy.

There are many examples of how effective energy management and saving can be achieved using renewable energy. One has to recall an example of a technological giant Google that recently celebrated 10 years of carbon neutrality, an achievement upheld by its commitment to energy efficiency, renewable energy, and energy efficient practices [42]. The application of energy efficiency and renewable energy strategies as a part of Google's activities is crucial to addressing the threat of climate change. Google's data centers are among the most efficient in the world and improve their environmental performance as demand for its software products increases dramatically. In 2017, the purchasing of renewable energies worldwide came at over 1 million tons of $\mathrm{CO}$-free energy per year. General Motors, which spends more than $\$ 1.2$ billion a year on energy, weaves energy efficiency into its long-term energy management plan [43]. This plan, which is closely linked to plant managers' remuneration, includes expected operational figures for the energy 
used to produce vehicles. If managers fail to meet energy targets, they have to explain to global leaders the reasons. The examples above demonstrate that energy companies must be closely involved in these practices as long-term strategic thinkers. Besides, they should advise their teams on how to integrate energy considerations into strategic priorities and processes. Moreover, one can play an essential role in helping organizations make more sustainable energy decisions. Thence, energy companies can support efforts to reduce energy consumption, and farmers can produce their own energy to become even more self-sufficient by reducing external inputs. Electricity, heating, lighting, and fuel can be produced for farm use, and renewable energy helps farmers save money and combat the effects of global warming. For example, Microsoft's renewable energy strategy sets so-called "aggressive targets" to hold the company accountable for its commitment to a sustainable energy future [44].

For most companies, the lack of adequate data and reliability makes it difficult to measure and manage energy strategies. There is so much value that an energy strategy must release and protect; so why are more companies not developing such a strategy? It can be shown that robust governance and management models are emerging that enable companies to address their gaps with Big Data processing and analyzing techniques that might bring in new insights and expand the decision-makers and stakeholders' horizons. Tools for measuring and managing energy and carbon are now available, and the data (including the Big Data) are relatively easy to collect [45]. Energy management can transform an organization into a sustainable organization and improve its financial performance in the energy sector, motivating to implement green habits. In addition, some groups of consumers are not aware that seemingly harmless habits can lead to energy waste and significant expenditures, such as the use of energy-efficient lighting, heating, and cooling. In this situation, organizations can be role models and promote better habits among their employees and customers. It becomes apparent that through motivation, training, and recognition that provide society with information, the world's business leaders might reduce waste and continue to lead in energy efficiency.

\section{Project Management in an Efficient Energy Consumption}

It can be seen that efficient energy consumption often depends on effective energy management. For instance, managing a building's energy consumption effectively and efficiently is key to reducing the cost of energy consumption and the risk of future energy shortages in any building [46,47]. Businesses and households monitor and assess their energy consumption with modern data-driven technologies [48]. Measuring the energy efficiency of buildings is crucial. Still, it is not legally binding and quite cumbersome in the real world, especially in large-scale projects such as energy storage and electricity generation [49].

To achieve the objectives described above, one needs to implement planned measures and procedures for energy saving and change the attitude of companies. Simple measures to determine energy savings provide step-by-step guidance for determining savings opportunities in existing plants for resource optimization and control of operating costs [50-52]. One of the solutions to initiate many sustainability initiatives is building projects. Sustainability can also be achieved in construction projects by using energy-efficient building materials such as solar panels and wind turbines.

Projects that are planned from a sustainable development point of view can be achieved by looking at sustainability projects afterward, rather than carrying them out naturally. This offers managers to pursue a comprehensive energy solution that allows them to select materials that contribute to energy saving. It covers all aspects of a building, including electrical track automation, a type of automatic tracking that allows temperature and energy consumption to be automatically tracked throughout the building, creating the most comfortable environment at the lowest cost. Utility managers, who are knowledgeable about how water and wastewater utilities use energy, might better manage the costs of operating any plant or business. It has been estimated that municipalities and utilities 
incorporating energy efficiency practices into their facilities can save 15 to 30 percent of energy and financial resources [53]. An important step is to be aware of the impact the managers have on their plant and prioritize improvements for the most efficient way of cost management and usage of the respective plant. This is due to the fact that the underlying energy consumption is determined by a combination of data on the energy consumption of the system from the power supply and the energy consumption.

The energy management teams typically use this data to measure energy efficiency, set expectations and budgets, and assess energy usage and consumption trends over time. It also enables organizations and contractors to access energy management tools to influence decision analysis. Powered by the energy management platform, assessment and monitoring techniques based on precise data such as the scorecards generate a scorecard for each energy - for the consumption of the retail location, for each plant that consumes energy, and for the total amount of energy consumed by each entity. This assessment is based on energy consumption activities, including initiatives related to energy efficiency projects. All of this might help unlock the full potential of the energy management platforms and reduce energy consumption and carbon footprint. Therefore, replacing obsolete energy infrastructure facilities with more efficient equipment effectively controls costs and reduces greenhouse gas emissions [54-56].

However, financing energy efficiency management projects can be a real challenge, and the energy costs are a significant part of the organization's total operating costs [57]. Cost reduction and efficiency improvement are critical objectives for the organizational performance. Rising energy costs, increasing interest in energy efficiency, and developing strategies for better management are driving efforts to reduce energy consumption in buildings and develop energy-efficient strategies for building design and management.

To give an example to support the arguments above, one can take a look at the market for solar energy, which has grown rapidly over the last decade. In order to tap into the full value of solar energy, companies have to find out how to control the timing of energy use. Besides, managers have to find solutions on how to increase properties' energyefficiency and compare the total energy efficiency of the plant to building portfolio. Some organizations offer free benchmarking and rewards programs that import data directly and provide a dashboard tool that managers can use to track energy use over time. One of the best practices in energy savings is the conduct of regular and thorough energy audits. The continuous pursuit of energy has proven to be an essential part of the energy management of buildings. Accurate and precise data (especially the Big Data that became accessible because of ICT possibilities) can offer clear insights into energy consumption and saving. Electronic interactive graphics and dashboards provide the opportunity to inform customers about the energy and water consumption of their building and monitor energy consumption. Deep energy retrofits are part of the whole building analysis and construction process, which can be achieved by modernizing lighting and HVAC systems.

Hence, through this balanced and well-monitored holistic building approach supported by ICT solutions (such as smart meters and sensors) and the data obtained from these sensors, an in-depth energy-saving approach can address many systems by combining energy efficiency improvements, such as controlled ventilation, air conditioning, and energy storage. Advanced energy conversion guides are available to builders and developers, as well as architects and engineers.

\section{COVID-19 and Energy Consumption: An Empirical Model}

The SARS-CoV-2 virus, first observed in Wuhan's city in China in December 2019 and soon spread worldwide, affected everyone, including policy-makers and the general public [58-60]. The virus that causes coronavirus disease (called COVID-19) introduced many changes, some of them quite grim but others being quite beneficial in terms of sustainable growth and energy consumption. However disastrous and dangerous it appeared to be, the COVID-19 pandemic had some positive impacts on global warming and climate change $[61,62]$. While the lockdown measures imposed on billions of people 
around the world have brought business as usual to a standstill, the associated estimated decline in global energy demand means that carbon dioxide emissions decreased. For example, in China, this reduction and the associated reduction in energy consumption means that by 2020, the total power consumed as a whole was expected to increase by more than 1000 megawatts (MW) - equivalent to $1.5 \%$ of the country's total electricity consumption [63]. In the United Kingdom, Spain, and Italy, where offices, factories, bars, restaurants, and theaters remain closed, energy consumption has fallen by an average of $10 \%$ [64]. All over the world, after the shutdowns of many large power plants, demand for electricity in factories and offices has declined. COVID-19 led to an economic downturn that has dampened energy demand of all kinds, but not only in the United States. Energy consumption, especially oil, has reached a 30-year low [65]. American consumers used the lowest amount of energy in April 2020 since September 1989, and consumption fell 14 percent from April 2019-the second-lowest since the EIA began monitoring the energy consumption in 1973. Moreover, April 2020 was the first month measures to mitigate the impact of COVID-19 were adopted, resulting in a reduction in energy consumption of more than 1.5 million barrels per day [66]. The huge drop in consumption was due to low prices and the resulting negative financial performance, as well as an oversupply of oil and natural gas, which led to lower prices. Over Easter of 2020, the Chongqing Gas and Petroleum Exchange published its annual report on energy consumption for the first half of the year. In April, consumption of crude oil, gas, and petroleum products in China fell by almost $25 \%$ compared to the same period the previous year, as the effects of the coronavirus continued to weigh on consumption [67].

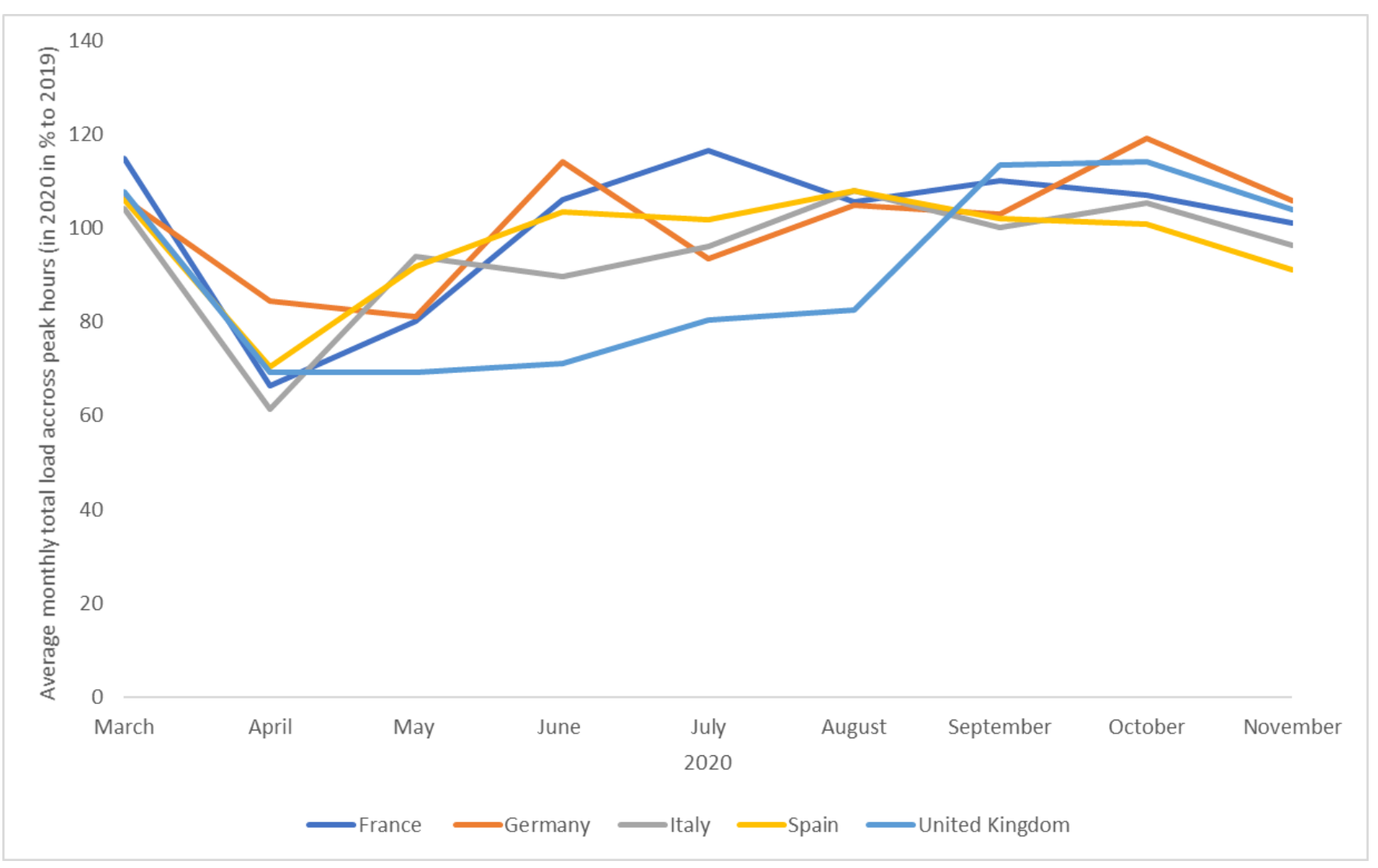

Figure 1. Average monthly electricity load in selected European Union (EU) countries for 2020 compared to 2019. Source: created by the authors based on $[68,69]$.

This was also the case for the EU Member States. Figure 1 depicted above shows this pattern representing the average monthly electricity load in selected EU countries for 2020 compared to 2019. The consumption of electric energy went down rapidly, especially in the 
first months of the pandemic's spread outside China, in Spring 2020, when the coronavirus still remained a big unknown and many countries around the world started lockdowns in an attempt to stop its spread and flatten the curve of the infected in order not to overburden their health systems. These effects were visible everywhere, but in the energy industry, it was easy to follow. According to industry sources, global energy demand fell by $3.8 \%$ in April 2020 due to the COVID-19 pandemic, with the greatest impact felt in Europe, North America, and elsewhere, where restrictions were enforced [70]. In the United States, electricity consumption continued to decline, while other parts of Europe were protected by less stringent measures and colder weather. According to the industry report, a growing number of the United Kingdom energy suppliers collapsed due to low prices and lack of demand for their products. China, a coal-based economy, was most affected by COVID-19 in the first quarter, but the mild weather also curbed coal consumption. Global coal demand was also hit hard in April, falling by almost 8\% compared with the first quarter of 2019 [71]. Coal is being challenged by the continued growth of RES such as wind and solar, as well as a decline in natural gas demand. Although China continues to use coal on a large scale as a raw material for power plants, the COVID-19 pandemic has helped accelerate coal phasing-out in many countries. Solar and wind power generation is estimated to increase by $1.5 \%$ to $2 \%$ annually, with an annual increase of $2-3 \%$ in the coming years [72]. This will drive the electricity mix away from fossil fuels and towards RES such as wind and solar. This general decline in energy consumption, combined with substantial progress in renewable technologies, has reduced energy and CO2 emissions between $1.5 \%$ and $2 \%$ per year [73]. Many environmentalists hoped that a silver lining to the pandemic would significantly reduce greenhouse gas emissions. In its annual report on global energy consumption, the International Energy Agency (IEA) estimates that consumption fell in countries with very strict lockouts in the spring [74].

Overall, the IAE expects energy demand to fall by $5 \%$, while carbon dioxide emissions from energy will fall by $7 \%$ even faster. As oil producers expect, planes, subways, and buses will empty more quickly than expected, leading to a glut of supply that will drive down prices. Experts add that this decline has not yet been fully translated into wholesale prices, which could reach as high as $\$ 20$ a barrel in the first half of the year, up from about $\$ 30$ a barrel in March 2020 [75]. Primary and final energy consumption has decreased by more than $1.3 \%$ compared to 2018, mainly due to milder temperature conditions and lower electricity prices. Fossil fuels remained stable at $75 \%$, while their share of total energy consumption rose to $7 \%$, while hydropower fell to $6 \%$. Gas also played a growing role, with electricity generation ( $9 \%$ ) becoming the largest energy source in the United States and the second-largest in the EU [76].

Equation (1) outlines the empirical model of the estimations of the adjusted electricity consumption impacted by the changes in consumption patterns due to the COVID-19 pandemic. The resulting model can be presented as follows:

$$
\text { load }_{i t}=\alpha_{i d}+\beta_{1} \text { day }+\beta_{2} \text { week }+\beta_{2} \text { hour }+\beta_{3} \text { holiday }+\varepsilon_{i t}
$$

where:

load is the country (i) hour ( $t$ ) level;

day is the day of the week;

week is the week of the year;

hour is the hour of the day;

holiday is the public holiday.

$\varepsilon$ is an error term.

The independent variables are represented by the set of locational dummies.

Based on research results (Table 1), results are presented of estimations using the data from the major EU economies represented by France, Germany, Italy, Spain, and the United Kingdom (which is also considered here even though it is technically not an EU country any longer starting from 2021). Study results demonstrate the anticipated changes in the 
adjusted electricity consumption expressed in percentage points (random errors are shown in brackets).

Table 1. Anticipated changes in the adjusted electricity consumption due to the COVID-19 pandemic.

\begin{tabular}{|c|c|}
\hline Country & Change, in \% \\
\hline France & $\begin{array}{l}-8.5 \\
(1.2)\end{array}$ \\
\hline Germany & $\begin{array}{l}-8.5 \\
(1.1)\end{array}$ \\
\hline Italy & $\begin{array}{c}-23.6 \\
(2.1)\end{array}$ \\
\hline Spain & $\begin{array}{c}-15.4 \\
(1.7)\end{array}$ \\
\hline United Kingdom & $\begin{array}{l}-7.5 \\
(2.5)\end{array}$ \\
\hline
\end{tabular}

Source: created by the authors.

Based on research results (Table 1), predicting the daily average electricity prices for the month to come is possible. Figure 2 demonstrates the average daily spot electricity prices for the baseload power in the selected EU countries, such as France, Germany, Italy, Spain, and the United Kingdom.

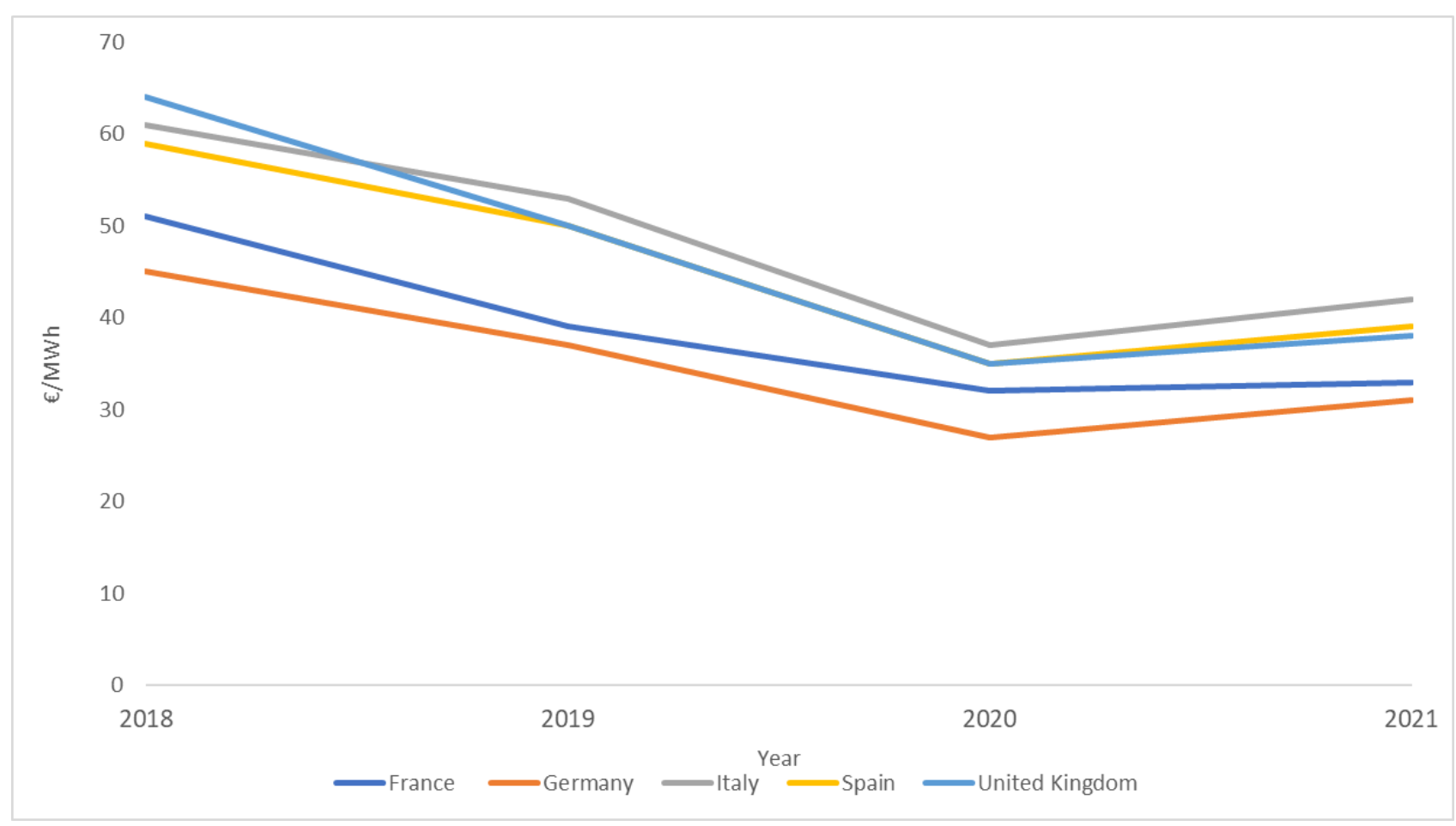

Figure 2. Average daily spot electricity prices for the baseload power in selected EU countries. Source: created by the authors.

Study results show that spending more time at home to slow the coronavirus spread is likely to increase household energy consumption and utility bills. While energy efficiency is a good antidote, implementing major energy modernization requires significant investment in one's own home, enabling many customers to avoid their homes during a pandemic. By saving and reducing pollution, effective energy management can create and preserve appropriate local jobs. It can also help homeowners retrofit their homes to reduce their monthly energy bills, boost the energy efficiency market for jobs and suppliers, and protect the environment by investing in clean and efficient technologies. The energy efficiency industry, which employed more than 2.3 million Americans before the pandemic, was hit 
hard by COVID-19 and has shed more than 400,000 jobs since the outbreak began. Energyefficient retrofits save consumers nearly $\$ 800$ billion in energy costs each year and save billions of dollars annually in health care, education, and other costs [77]. New management solutions considering energy efficiency might help the energy sector invest in much-needed training to create new opportunities for its workers. Energy efficiency policies may be far from supporting the frontline combatants of the COVID-19 pandemic and raising the bills of people struggling during devastating health and economic crisis. If state utilities and other sponsors stop the majority of energy efficiency programs, the program's implementors could face harsh economic consequences. Energy-saving programs can help make buildings healthier and more comfortable while maintaining jobs. By reducing electricity and gas bills, these programs also help free up much-needed money that can be used for education, health care, and vocational training of workers in the energy-efficient sector.

Looking at the energy efficiency industry insiders, one can see their dire situation when many employers are in the field of energy efficiency. It covers the dramatic energy efficiency cuts caused by COVID-19 and its analysis of this pandemic's economic impact on the United States energy industry. In addition, to be absorbed by other sectors such as the oil and gas industry and the financial services sector, it is also being hit hard by the collapse in oil prices, job losses, and investment in renewable energy, as well as a decline in demand for energy-efficient equipment. In addition to the huge economic benefits, investments in energy efficiency reduce air and water pollution, keep utility bills affordable, and make homes and jobs healthier and more comfortable. Indeed, many studies have shown that health-care costs rise when homes, schools, and the workplace get energy-efficiency upgrades. Energy efficiency in the workplace makes it much easier to challenge the current restrictions on residence at home. Moreover, investment in energy conversion - that is, the burning of household appliances for efficient versions-can revive the economy and get people back to work. As the short-term moratorium on shutting down utilities expires, people in economic need will be able to pay their energy bills at the time when they need them most. This will facilitate the expansion of efficiency programs to reduce utility bills in the short and long term. Before the pandemic, nearly 2.4 million people were working in the United States energy efficiency sector. At the beginning of June 2020 , the thriving efficiency sector had lost only $1.5 \%$ of its workforce, but by the end of the year, a $3 \%$ increase in the energy efficiency workforce was forecast [78]. These workers include HVAC technicians working on highly efficient systems, production workers who make LED lighting, and efficient building materials that were not installed as usual during the pandemic.

\section{ICT Solutions and the Effective Management of Energy Resources}

Renewable energy is currently the best solution to global warming and climate change and is one of the most promising technologies that might change facilitate the management of energy resources. In order to explore the obvious potential of renewable energy, researchers look at all aspects from energy efficiency to energy storage and storage technologies [79-81]. These aspects can be roughly divided into three categories: energy efficiency, energy storage, and renewable energy [82]. While the development of other alternative energy sources, including solar power, wind power, and hydro energy storage, is essential, it seems that the traditional energy sources and nuclear energy cannot meet the growing energy demand. Therefore, to face the climate challenges and the population's growth (which might be riddled by the infectious diseases such as COVID-19), one needs to manage an effective transition towards renewable energy. Nevertheless, this process would be impossible without the efficient technologies and ICT solutions $[83,84]$.

Figure 3 presents a graphical interpretation of the optimal position of ICT in effective energy management. ICT (depicted in the center) represented by the wireless mobile technologies (perhaps, 5G wireless networks that are currently being introduced worldwide or more advanced data transmission technologies that are envisaged in the future) is the 
link between the producers and suppliers of traditional and renewable energy as well as peer-to-peer (P2P) prosumers and households.

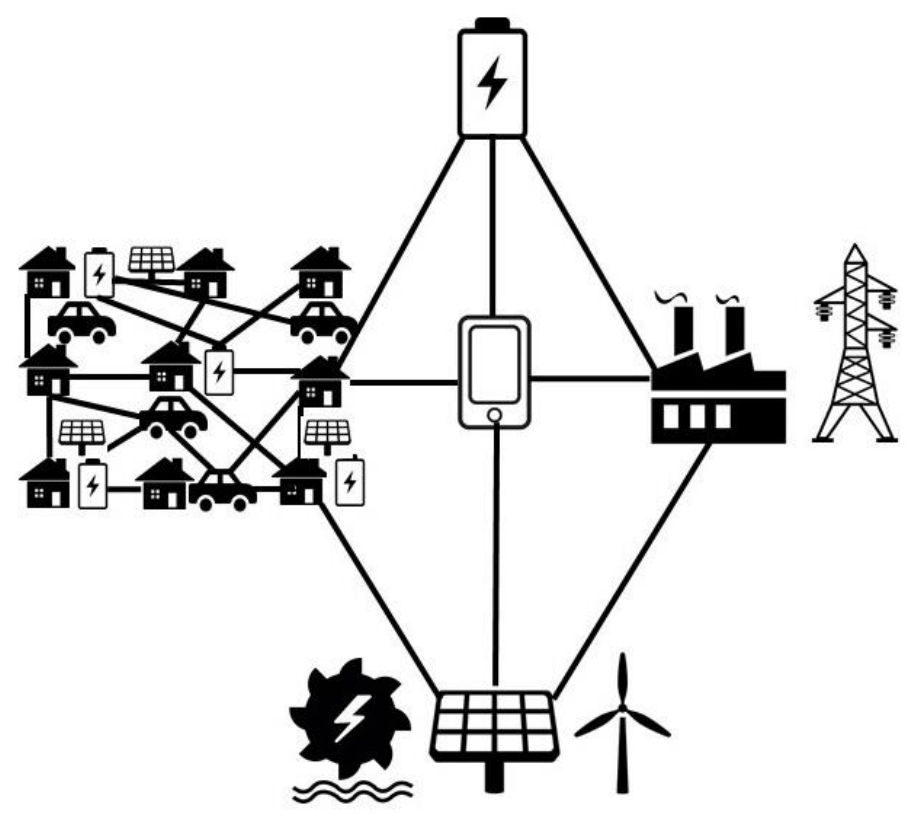

Figure 3. Information and communication technology (ICT) in effective energy management. Source: created by the authors.

Based on scientific research results, ICT helps keep the environment more sustainable by incorporating more efficient renewable energy $[85,86]$. When it comes to human mobility, almost all forms of transport rely heavily on fossil fuels, with gasoline and diesel-powered vehicles dominating worldwide. Since the mid-20th century, the use of petroleum, gasoline, diesel, and oil-based fuels has given exporting countries enormous economic and political influence. This has led to soaring oil prices, but several countries such as Denmark, Germany or Norway, for example, have survived by developing and using alternative energy generation systems, even though they use fuels made from petroleum.

Renewable energy should be the main alternative to fossil fuels, and in some countries as for example Denmark, Germany, or Norway have made rapid progress in energy efficiency due to the ICT solutions. Given the expected increase in fossil fuel use in transport and energy production, many countries need to make further progress in further development to reduce emissions and solve the problem of climate change.

Many developed countries continue to make significant progress in developing their own alternative energy systems. In Japan, nuclear power is cheaper than oil, and in South Korea, less than half the cost of oil production. Each MWh of renewable electricity belongs to the end-user, but it only carries a fraction of the cost of feeding it into the grid. The origin guarantees help minimize the cost of new investments in renewable energy and reinvest the price of electricity in new ones. Renewable energy certificates provide highquality renewable energy and have the potential to bring significant economic benefits to developing countries. These eco-labeled certificates are designed with business behavior to support the local economy by ensuring additional benefits for local communities.

Another example is the Gold Standard, which is based on renewable energy products. Forward-looking companies can already expect to take advantage of the transition from fossil fuels and the integration of renewable energy into their business by using labeled renewable energy certificates. Hence, ICT solutions can save financial resources, reduce risks, increase brand equity by aligning with the United Nation's Sustainable Development Goals. By opting for a more sustainable approach to their energy investments, companies begin to use renewable energy as a means of attracting and retaining employees, customers, and investors, not only in the short term but also in the long term. 
Global warming is a serious threat and has a catastrophic effect worldwide. In order to mitigate the threat of global warming, countries and regions must rely on clean renewable energy sources. Energy solutions to combat global warming can be combated by reducing enormous carbon dioxide emissions and refraining from climate-damaging technologies. Energy storage and energy management also represent significant challenges, especially when intelligent and autonomous sensors for data centers are smart meters and ICT-powered solutions are involved. The ideal scenario is an ICT system that integrates energy storage with energy harvesting components to provide power to the electronic sensor, communication, and display components. That will operate over an estimated lifetime of years. There is a need to bridge the gap between the power harvesting component and the electronic component in order to achieve true autonomy. This is because the energy requirement for electronics must be reduced, and the efficiency of energy harvesters increased.

The current production of semiconductor devices has reached a fundamental efficiency limit, the so-called energy wall, which prevents any reduction in energy consumption when transistor sizes are scaled to upcoming technology nodes. Based on current projections, a ten-fold improvement in the energy efficiency of chips is needed to maintain the scalability of information technology over the next decade. Based on current technology, there is no new architecture that could significantly reduce power consumption or improve switching devices, and the ultimate limit of architectural design is almost impossible to derive. The so-called "economic meltdown trend" in embedded systems will lead to a significant increase in cooling energy costs in the foreseeable future.

\section{Conclusions}

This study analyzed how effective energy consumption management is conducted nowadays, especially when it has to face some new and unexpected challenges such as the recent COVID-19 pandemic. This research also focused on the role and place of ICT solutions within these energy management strategies and approaches.

In general, it turns out that almost all sectors of the world's economy were negatively affected by the COVID-19 pandemic and that the energy efficiency sector was not an exception. Widespread layoffs and risks in the clean energy sector are upsetting an industry that once led the job creation in many countries. For example, in the United States, there were nearly 70 thousand applications for unemployment benefits from the energy efficiency workers, which is only a small fraction of the industry's total number of jobs. In the United States, clean energy employment has grown to nearly 3.4 million workers and is on the rise. Energy efficiency remains one of the most profitable sectors in the United States energy sector, employing 2 to 4 million Americans. If it was to absorb the job losses in energy efficiency and other clean energy sectors, it could lose a net 1.5 million jobs in this sector. In addition to the obvious significant economic benefits, investments in energy efficiency might ensure that utility bills remain affordable, air and water pollution are reduced, and homes and jobs are healthier and more comfortable. Indeed, many studies have shown that health-care costs fall when homes, schools, or workplaces are upgraded to be energy-efficient. A huge factor in one's energy bill is how much energy one uses, and if one is at home more, that energy consumption could change. Nature and energy efficiency of a person at work makes it difficult to question the current restrictions on staying at home. If a person raises the thermostat by only one or two degrees in warmer weather and lowers it by one or two degrees in winter, the customer can keep the bill lower than it would otherwise be. However, the person in question needs to realize these outcomes, so they need to be educated on the benefits of energy-saving and efficiency.

But the energy-saving behavior should also be based on the balanced demand-side response, which needs to incorporate a two-way flow of data on energy consumption and pricing. Energy users and consumers (both households and business companies) should be encouraged to reduce their energy consumption consciously. Energy users and consumers (both households and business companies) should be appropriately informed 
through national government policies, programs, and channels to encourage them to reduce energy consumption consciously. They should be reminded about this constantly from all possible directions.

The problem with effective energy management remains that many customers do not realize that one of the most effective ways to increase energy efficiency in their homes is to change their daily habits. For example, switching off lights and appliances when they are not in use can save energy and money over the course of a month. It would also be beneficial to educate the energy consumers about how energy providers align their programs to serve customers when business realities change and energy efficiency workers are worried about the impact of climate change on their customers' energy consumption. Utilities also promote self-installed products such as smart thermostats and energy-efficient devices that can lead to large energy savings. Giving recommendations to reduce energy consumption and increase living comfort and tips on companies' energy efficiency might also help a great deal to businesses and end customers. Critics argue that the full savings from efficiency are inflated by "cash-in" programs in which utility customers pocket money through upgrades they would have made anyway. This may be a legitimate concern in a few cases, but it is no reason to cut the energy efficiency programs.

While energy efficiency can lead to significant savings in the form of lower energy costs for utilities and other businesses, the full benefits of efficiency will not be realized until the multi-billion-dollar infrastructure projects built over time will start yielding profits. Small companies operating on tight margins can save energy efficiency gains by improving profitability and competitiveness. Suppose these programs are cut, which would provide little relief to customers now and potentially impose huge rate increases on them in the years ahead. In that case, there is no reason why such a move, which discredits energy efficiency, would ultimately harm credit rating agencies. Suppose households continue to be burdened by the COVID-19 virus. In that case, the one that caused the economic downturn, these savings will be even more important to the economy than the investments in energy efficiency. However, these flows conceal a significant gap, with only $12 \%$ of the 2017 flows reaching developing countries and only $5 \%$ reaching the least developed countries.

When it comes to the study's novelty aspects, this research demonstrated how the COVID-19 virus pandemic was reflected in energy consumption and energy prices (an example of the selected EU countries was employed to show the impacts). Research results show that adjusted electricity consumption, as well as the average daily spot electricity prices for the baseload power, declined considerably, causing fundamental changes that are resulting in cutting the redundant business costs and tipping the scale of the energy balance towards RES, which would envisage the wider application of the ICT solutions for the more effective management of energy resources in the future.

Overall, there is a pressing need for bold international cooperation to bridge the gap in access to energy is more important than ever. Improving international cooperation, including strong public-private engagement and increasing financial flows, is crucial to accelerating renewable energy deployment in developing countries to accelerate the transition to a low-carbon, clean future powered by renewable energy solutions for individuals.

When it comes to pathways for further research, the recommendation is to look at various ICT solutions for effective energy management and energy efficiency that include the extended use of Big Data as well as applying artificial intelligence for analyzing the demand and supply of energy and augmented reality for presenting the results of this analysis to consumers and policy-makers. Another prospective field of research is peerto-peer energy markers, where energy prosumers would trade with each other, buying energy as well as selling it back to the grid. It would also be valuable to study how all these ICT innovations find their way into efficient energy management in the aftermath of the COVID-19 pandemic that is clearly changing the rules on the energy markets and removing lots of administrative burdens that would have usually taken years to overcome. 
Author Contributions: Conceptualization, W.S., I.F., I.L., J.R., and M.T.; Methodology, W.S., I.F., I.L., J.R., and M.T.; Formal Analysis, W.S., J.R., and M.T.; Resources, I.F. and I.L.; Data Curation, W.S., J.R., and M.T.; Writing—Original Draft Preparation, W.S., I.F., I.L., J.R., and M.T.; Writing-Review \& Editing, W.S., I.F., I.L., J.R., and M.T.; Visualization, W.S. All authors have read and agreed to the published version of the manuscript.

Funding: This research received no external funding.

Institutional Review Board Statement: Not applicable.

Informed Consent Statement: Not applicable.

Data Availability Statement: Not applicable.

Conflicts of Interest: The authors declare no conflict of interest.

\section{References}

1. Li, H.X.; Edwards, D.J.; Hosseini, M.R.; Costin, G. A review on renewable energy transition in Australia: An updated depiction. J. Clean. Prod. 2020, 242, 118475. [CrossRef]

2. Vakulchuk, R.; Overland, I.; Scholten, D. Renewable energy and geopolitics: A review. Renew. Sustain. Energy Rev. 2020, 122, 109547. [CrossRef]

3. Newbery, D.; Pollitt, M.G.; Ritz, R.A.; Strielkowski, W. Market design for a high-renewables European electricity system. Renew. Sustain. Energy Rev. 2018, 91, 695-707. [CrossRef]

4. Hsu, A.; Tan, J.; Ng, Y.M.; Toh, W.; Vanda, R.; Goyal, N. Performance determinants show European cities are delivering on climate mitigation. Nat. Clim. Chang. 2020, 10, 1015-1022. [CrossRef]

5. Dudin, M.N.; Frolova, E.E.; Protopopova, O.V.; Mamedov, O.; Odintsov, S.V. Study of innovative technologies in the energy industry: Nontraditional and renewable energy sources. Entrep. Sustain. Issues 2019, 6, 1704-1713. [CrossRef]

6. Ang, B.; Su, B. Carbon emission intensity in electricity production: A global analysis. Energy Policy 2016, 94, 56-63. [CrossRef]

7. Wang, Q.; Jiang, X.-T.; Yang, X.; Ge, S. Comparative analysis of drivers of energy consumption in China, the USA and India-A perspective from stratified heterogeneity. Sci. Total Environ. 2020, 698, 134117. [CrossRef] [PubMed]

8. Elavarasan, R.M.; Afridhis, S.; Vijayaraghavan, R.R.; Subramaniam, U.; Nurunnabi, M. SWOT analysis: A framework for comprehensive evaluation of drivers and barriers for renewable energy development in significant countries. Energy Rep. 2020, 6, 1838-1864. [CrossRef]

9. Lu, H.; Guo, L.; Zhang, Y. Oil and gas companies' low-carbon emission transition to integrated energy companies. Sci. Total Environ. 2019, 686, 1202-1209. [CrossRef] [PubMed]

10. Liu, Y.; Zheng, R.; Chen, S.; Yuan, J. The economy of wind-integrated-energy-storage projects in China's upcoming power market: A real options approach. Resour. Policy 2019, 63, 101434. [CrossRef]

11. Bazilian, M.; Bradshaw, M.; Goldthau, A.; Westphal, K. Model and manage the changing geopolitics of energy. Nat. Cell Biol. 2019, 569, 29-31. [CrossRef]

12. Zhu, L.; Xu, Y.; Pan, Y. Enabled comparative advantage strategy in China's solar PV development. Energy Policy 2019, 133, 110880. [CrossRef]

13. Xu, M.; Xie, P.; Xie, B.-C. Study of China's optimal solar photovoltaic power development path to 2050. Resour. Policy 2020, 65, 101541. [CrossRef]

14. Lin, B.; Bae, N.; Bega, F. China's Belt \& Road Initiative nuclear export: Implications for energy cooperation. Energy Policy 2020, 142, 111519. [CrossRef]

15. Ou, S.; Hao, X.; Lin, Z.; Wang, H.; Bouchard, J.; He, X.; Przesmitzki, S.; Wu, Z.; Zheng, J.; Lv, R.; et al. Light-duty plug-in electric vehicles in China: An overview on the market and its comparisons to the United States. Renew. Sustain. Energy Rev. 2019, 112, 747-761. [CrossRef]

16. Igaliyeva, L.; Niyazbekova, S.; Serikova, M.; Kenzhegaliyeva, Z.; Mussirov, G.; Zueva, A.; Tyurina, Y.G.; Maisigova, L.A. Towards environmental security via energy efficiency: A case study. Entrep. Sustain. Issues 2020, 7, 3488-3499. [CrossRef]

17. Shah, S.; Zhou, P.; Walasai, G.; Mohsin, M. Energy security and environmental sustainability index of South Asian countries: A composite index approach. Ecol. Indic. 2019, 106, 105507. [CrossRef]

18. Polozova, T.; Musiienko, V.; Storozhenko, O.; Peresada, О.; Геселева, Н. Modeling of energy-saving processes in the context of energy safety and security. J. Secur. Sustain. Issues 2019, 8, 387-397. [CrossRef]

19. Sun, X.; Liu, X. Decomposition analysis of debt's impact on China's energy consumption. Energy Policy 2020, 146, 111802. [CrossRef]

20. Guo, X.; Lin, K.; Huang, H.; Li, Y. Carbon footprint of the photovoltaic power supply chain in China. J. Clean. Prod. 2019, 233, 626-633. [CrossRef]

21. Lewis, J.I. Toward a New Era of US Engagement with China on Climate Change. Georget. J. Int. Aff. 2020, 21, 173-181. [CrossRef]

22. Warner, K.; Jones, G.A. The 21st Century Coal Question: China, India, Development, and Climate Change. Atmosphere 2019, 10, 476. [CrossRef]

23. Warner, K.; Jones, G.A. The Climate-Independent Need for Renewable Energy in the 21st Century. Energies 2017, 10, 1197. [CrossRef] 
24. Siwal, S.S.; Zhang, Q.; Devi, N.; Thakur, V.K. Carbon-Based Polymer Nanocomposite for High-Performance Energy Storage Applications. Polymers 2020, 12, 505. [CrossRef]

25. Zhang, H.; Zhang, X.; Yuan, J. Coal power in China: A multi-level perspective review. Wiley Interdiscip. Rev. Energy Environ. 2020, 9, 386. [CrossRef]

26. Kober, T.; Schiffer, H.-W.; Densing, M.; Panos, E. Global energy perspectives to 2060—WEC's World Energy Scenarios 2019. Energy Strat. Rev. 2020, 31, 100523. [CrossRef]

27. Tvaronavičienè, M.; Ślusarczyk, B. Energy Transformation Towards Sustainability; Elsevier BV: Amsterdam, The Netherlands, 2020; p. 333.

28. Wu, X.; Guo, J.I.; Jiashuo, L.; Chen, G. Energy use in world economy from household-consumption-based perspective. Energy Policy 2019, 127, 287-298. [CrossRef]

29. Halkos, G.; Gkampoura, E.-C. Reviewing Usage, Potentials, and Limitations of Renewable Energy Sources. Energies 2020, 13, 2906. [CrossRef]

30. Fernández-Guillamón, A.; Gómez-Lázaro, E.; Muljadi, E.; Molina-García, Á. Power systems with high renewable energy sources: A review of inertia and frequency control strategies over time. Renew. Sustain. Energy Rev. 2019, 115, 109369. [CrossRef]

31. Rayati, M.; Goghari, S.A.; Gheidari, Z.N.; Ranjbar, A. An optimal and decentralized transactive energy system for electrical grids with high penetration of renewable energy sources. Int. J. Electr. Power Energy Syst. 2019, 113, 850-860. [CrossRef]

32. Hoegh-Guldberg, O.; Jacob, D.; Taylor, M.; Bolaños, T.G.; Bindi, M.; Brown, S.; Camilloni, I.A.; Diedhiou, A.; Djalante, R.; Ebi, K.; et al. The human imperative of stabilizing global climate change at $1.5^{\circ} \mathrm{C}$. Science 2019, 365, eaaw6974. [CrossRef] [PubMed]

33. Khan, N.; Dilshad, S.; Khalid, R.; Kalair, A.R.; Abas, N. Review of energy storage and transportation of energy. Energy Storage 2019, 1, 49. [CrossRef]

34. Poudyal, R.; Loskot, P.; Nepal, R.; Parajuli, R.; Khadka, S.K. Mitigating the current energy crisis in Nepal with renewable energy sources. Renew. Sustain. Energy Rev. 2019, 116, 109388. [CrossRef]

35. Hawkins, K. Primary Energy Consumption. 2015. Available online: https:/ / www.masterresource.org/energy-sources/primaryenergy-electricity-ii/ (accessed on 29 November 2020).

36. El Iysaouy, L.; Idrissi, N.E.A.E.; Tvaronavičienè, M.; Lahbabi, M.; Oumnad, A. Towards energy efficiency: Case of Morocco. Insights into Reg. Dev. 2019, 1, 259-271. [CrossRef]

37. Sapkota, K.; Oni, A.O.; Kumar, A.; Linwei, M. The development of a techno-economic model for the extraction, transportation, upgrading, and shipping of Canadian oil sands products to the Asia-Pacific region. Appl. Energy 2018, 223, 273-292. [CrossRef]

38. Zhang, Z.; Chong, A.; Pan, Y.; Zhang, C.; Lam, K.P. Whole building energy model for HVAC optimal control: A practical framework based on deep reinforcement learning. Energy Build. 2019, 199, 472-490. [CrossRef]

39. Rausser, G.; Strielkowski, W.; Streimikiene, D. Smart meters and household electricity consumption: A case study in Ireland. Energy Environ. 2017, 29, 131-146. [CrossRef]

40. WBDG. Optimize Energy Use. 2018. Available online: https://www.wbdg.org/design-objectives/sustainable/optimize-energyuse (accessed on 1 December 2020).

41. Brown, M.A.; Soni, A. Expert perceptions of enhancing grid resilience with electric vehicles in the United States. Energy Res. Soc. Sci. 2019, 57, 101241. [CrossRef]

42. Google. Environmental Report. Available online: https://services.google.com/fh/files/misc/google_2019-environmentalreport.pdf (accessed on 19 November 2020).

43. Trainer, D. General Motors Is Making a Turn for the Better. 2020. Available online: https://www.forbes.com/sites/greatspeculations/ 2020/07/28/general-motors-is-making-a-turn-for-the-better/?sh=6154f26664fa (accessed on 28 November 2020).

44. Winston, A.; Favaloro, G.; Healy, T. Energy strategy for the C-suite. Harv. Bus. Rev. 2017, 95, 139-146.

45. Zhou, K.; Fu, C.; Yang, S. Big data driven smart energy management: From big data to big insights. Renew. Sustain. Energy Rev. 2016, 56, 215-225. [CrossRef]

46. Klemeš, J.J.; Van Fan, Y.; Jiang, P. The energy and environmental footprints of COVID-19 fighting measures-PPE, disinfection, supply chains. Energy 2020, 211, 118701. [CrossRef]

47. Gopinath, R.; Kumar, M.; Joshua, C.P.C.; Srinivas, K. Energy management using non-intrusive load monitoring techniques-Stateof-the-art and future research directions. Sustain. Cities Soc. 2020, 62, 102411. [CrossRef]

48. Sarma, U.; Karnitis, G.; Zuters, J.; Karnitis, E. District heating networks: Enhancement of the efficiency. Insights Reg. Dev. 2019, 1, 200-213. [CrossRef]

49. Roth, J.; Lim, B.; Jain, R.K.; Grueneich, D. Examining the feasibility of using open data to benchmark building energy usage in cities: A data science and policy perspective. Energy Policy 2020, 139, 111327. [CrossRef]

50. Sabia, G.; Petta, L.; Avolio, F.; Caporossi, E. Energy saving in wastewater treatment plants: A methodology based on common key performance indicators for the evaluation of plant energy performance, classification and benchmarking. Energy Convers. Manag. 2020, 220, 113067. [CrossRef]

51. Gaspari, J.; Fabbri, K.; Gabrielli, L. A Study on Parametric Design Application to Hospital Retrofitting for Improving Energy Savings and Comfort Conditions. Buildings 2019, 9, 220. [CrossRef]

52. Nguyen, P.V.; Tran, K.T. Explicating energy saving intention from the prospect of small medium enterprises. Entrep. Sustain. Issues 2020, 8, 716-734. [CrossRef] 
53. EPA. Energy Efficiency for Water Utilities. 2020. Available online: https://www.epa.gov/sustainable-water-infrastructure/ energy-efficiency-water-utilities (accessed on 8 December 2020).

54. Lisin, E.; Shuvalova, D.; Volkova, I.; Strielkowski, W. Sustainable Development of Regional Power Systems and the Consumption of Electric Energy. Sustainability 2018, 10, 1111. [CrossRef]

55. Tishkov, S.; Shcherbak, A.; Karginova-Gubinova, V.; Volkov, A.; Tleppayev, A.; Pakhomova, A. Assessment the role of renewable energy in socio-economic development of rural and Arctic regions. Entrep. Sustain. Issues 2020, 7, 3354-3368. [CrossRef]

56. Sola, A.V.H.; Mota, C.M. Influencing factors on energy management in industries. J. Clean. Prod. 2020, 248, 119263. [CrossRef]

57. Romprasert, S.; Jermsittiparsert, K. Energy Risk Management and Cost of Economic Production Biodiesel Project. Int. J. Energy Econ. Policy 2019, 9, 349-357. [CrossRef]

58. Younes, N.; Al-Sadeq, D.W.; Al-Jighefee, H.; Younes, S.; Al-Jamal, O.; Daas, H.I.; Yassine, H.M.; Nasrallah, G.K. Challenges in Laboratory Diagnosis of the Novel Coronavirus SARS-CoV-2. Viruses 2020, 12, 582. [CrossRef]

59. Firth, J.A.; Hellewell, J.; Klepac, P.; Kissler, S.; Kucharski, A.J.; Spurgin, L.G. Using a real-world network to model localized COVID-19 control strategies. Nat. Med. 2020, 26, 1616-1622. [CrossRef]

60. Rezk, M.R.A.; Piccinetti, L.; Radwan, A.; Salem, N.M.; Sakr, M.M.; Khasawneh, A. Egypt beyond COVID 19, the best and the worst-case scenarios. Entrep. Sustain. Issues 2020, 8, 147-162. [CrossRef]

61. Manzanedo, R.D.; Manning, P. COVID-19: Lessons for the climate change emergency. Sci. Total Environ. 2020, $742,140563$. [CrossRef] [PubMed]

62. Norouzi, N.; De Rubens, G.Z.; Choupanpiesheh, S.; Enevoldsen, P. When pandemics impact economies and climate change: Exploring the impacts of COVID-19 on oil and electricity demand in China. Energy Res. Soc. Sci. 2020, 68, 101654. [CrossRef] [PubMed]

63. Robertson, S. How Is the Coronavirus Pandemic Affecting the Renewable Energy Industry? 2020. Available online: https: / / www.azocleantech.com/article.aspx?ArticleID=1094 (accessed on 3 December 2020).

64. Rupani, P.F.; Nilashi, M.; Abumalloh, R.A.; Asadi, S.; Samad, S.; Wang, S. Coronavirus pandemic (COVID-19) and its natural environmental impacts. Int. J. Environ. Sci. Technol. 2020, 17, 4655-4666. [CrossRef]

65. Hamdaoui, M. Oil Markets in the Post-Covid-19 World. 2020. Available online: https://trendsresearch.org/wp-content/uploads/ 2020/09/Oil-Markets-in-the-Post-Covid-19.pdf (accessed on 4 December 2020).

66. Mills, A. Energy Consumption Falls Amid COVID-19 Pandemic. 2020. Available online: https://eu.reporternews.com/story/ money/business/local/2020/08/01/alex-mills-energy-consumption-falls-amid-covid-19-pandemic/5549236002/ (accessed on 4 December 2020).

67. IEA. Global Energy Review 2020; IEA: Paris, France, 2020; Available online: https:/ /www.iea.org/reports/global-energy-review2020 (accessed on 1 December 2020).

68. Bruegel Datasets. Bruegel Electricity Tracker of COVID-19 Lockdown Effects. Available online: https://www.bruegel.org/ publications / datasets / bruegel-electricity-tracker-of-covid-19-lockdown-effects/ (accessed on 6 December 2020).

69. ENTSO-E 2020. Daily Power Consumption. Available online: https:/ / www.entsoe.eu/data/ (accessed on 20 October 2020).

70. Abu-Rayash, A.; Dincer, I. Analysis of the electricity demand trends amidst the COVID-19 coronavirus pandemic. Energy Res. Soc. Sci. 2020, 68, 101682. [CrossRef]

71. Wang, Q.; Lu, M.; Bai, Z.; Wang, K. Coronavirus pandemic reduced China's CO2 emissions in short-term, while stimulus packages may lead to emissions growth in medium- and long-term. Appl. Energy 2020, 278, 115735. [CrossRef]

72. Javed, M.S.; Ma, T.; Jurasz, J.; Amin, M.Y. Solar and wind power generation systems with pumped hydro storage: Review and future perspectives. Renew. Energy 2020, 148, 176-192. [CrossRef]

73. Razmjoo, A.; Kaigutha, L.G.; Rad, M.V.; Marzband, M.; Davarpanah, A.; Denai, M. A Technical analysis investigating energy sustainability utilizing reliable renewable energy sources to reduce CO2 emissions in a high potential area. Renew. Energy 2021, 164, 46-57. [CrossRef]

74. The Economist. Energy's Covid Recovery. 2020. Available online: https://www.economist.com/graphic-detail/2020/10/15 /energys-covid-recovery (accessed on 6 December 2020).

75. ENEA. Energy: COVID Impact on Consumption-March: $-15 \%$ and Record Fall in $\mathrm{CO}_{2}$ Emissions ISPRED Index -8\%. 2020. Available online: https:/ / www.enea.it/en/news-enea/news/energy-covid-impact-on-consumption-2212-march-15-and-recordfall-in-co2-emissions-ispred-index-8 (accessed on 5 December 2020).

76. Eurostat. Energy Production and Imports. 2020. Available online: https://ec.europa.eu/eurostat/statistics-explained/pdfscache/ 1216.pdf (accessed on 29 November 2020).

77. E2. COVID-19 \& The Clean Energy Economy. 2020. Available online: https://e2.org/buildbackbetter/covid-19-clean-energyeconomy (accessed on 5 December 2020).

78. EED. Pandemic Hurts Efficiency Jobs but You Can Still Make Energy-Saving Upgrades. 2020. Available online: https: / / energyefficiencyday.org/the-pandemic-is-hurting-efficiency-jobs-but-you-can-still-make-energy-upgrades (accessed on 29 November 2020).

79. Baldinelli, A.; Barelli, L.; Bidini, G.; Discepoli, G. Economics of innovative high capacity-to-power energy storage technologies pointing at $100 \%$ renewable micro-grids. J. Energy Storage 2020, 28, 101198. [CrossRef]

80. Liu, Y.; Du, J.-L. A multi criteria decision support framework for renewable energy storage technology selection. J. Clean. Prod. 2020, 277, 122183. [CrossRef] 
81. Plèta, T.; Tvaronavičienè, M.; Della Casa, S.; Agafonov, K. Cyber-attacks to critical energy infrastructure and management issues: Overview of selected cases. Insights Reg. Dev. 2020, 2, 703-715. [CrossRef]

82. Iris, Ç.; Lam, J.S.L. A review of energy efficiency in ports: Operational strategies, technologies and energy management systems. Renew. Sustain. Energy Rev. 2019, 112, 170-182. [CrossRef]

83. Sinsel, S.R.; Riemke, R.L.; Hoffmann, V.H. Challenges and solution technologies for the integration of variable renewable energy sources-A review. Renew. Energy 2020, 145, 2271-2285. [CrossRef]

84. Gielen, D.; Boshell, F.; Saygin, D.; Bazilian, M.D.; Wagner, N.; Gorini, R. The role of renewable energy in the global energy transformation. Energy Strat. Rev. 2019, 24, 38-50. [CrossRef]

85. Li, Y.; Li, Y.; Gao, D.W.; Zhou, J. Distributed Optimal Energy Management for Energy Internet. IEEE Trans. Ind. Informatics 2017, 13, 3081-3097. [CrossRef]

86. Ahl, A.; Yarime, M.; Tanaka, K.; Sagawa, D. Review of blockchain-based distributed energy: Implications for institutional development. Renew. Sustain. Energy Rev. 2019, 107, 200-211. [CrossRef] 